\title{
Sociobiology
}

RESEARCH ARTICLE - WASPS

\section{Nesting Ecology of Polistes Species (Hymenoptera, Vespidae) in Urban Areas of South- western Iberian Peninsula}

\author{
JL PÉREZ-Bote, C MORA-RuBIO
}

Department of Zoology, Faculty of Sciences, University of Extremadura, 06006 Badajoz, Spain

\section{Article History}

\section{Edited by}

Fabio Nascimento, USP, Brazil

Received $\quad 19$ November 2019

Initial acceptance 28 July 2020

Final acceptance 13 August 2020

Publication date 30 September 2020

\section{Keywords}

Urbanization, nest abundance, nest substrates, nest orientation.

\section{Corresponding author}

JL Pérez-Bote

Department of Zoology

Faculty of Sciences

University of Extremadura

Av. de Elvas s/no, 06006 Badajoz, Spain.

E-Mail: jlperez@unex.es

\begin{abstract}
Urbanization is increasing across the globe and it is recognized as a major factor affecting species, populations and assemblages. Although urbanization is recognized as a major threat to biodiversity, there is increasing evidence that urban habitats may play a role in conservation. The objective of this work was to verify the occurrence of Polistes species (Vespidae) and the substrates used for nesting in urban areas in south-western Iberian Peninsula. The study was carried out from March to August of 2018 in three small towns in the Llanos de Olivenza region (SW Spain). Active searching was conducted for colonies of social wasps along and for each colony that was found we identified the species, type of substrate used for nesting, height of the colony in relation to the ground level and orientation. 753 colonies of social wasps were found belonging to two species: Polistes dominula and $P$. gallicus. The most used nesting substrate was clay roof tile followed by metals. The height of the nests was related to the height of the buildings on which they were built. In all the tree towns nests exposure were oriented to the SE with mean angle values oscillating between $127.42^{\circ}$ and $140.68^{\circ}$. In addition, our results confirm the prediction that wasps are more abundant in less or non-urbanized areas even if they are small urban areas such as those studied in our case.
\end{abstract}

\section{Introduction}

Urbanization is increasing across the globe and it is recognized as a major factor affecting species, populations and assemblages (Turner et al., 2004; Grimm et al., 2008). Although urbanization is recognized as a major threat to biodiversity, there is increasing evidence that urban habitats may play a role in conservation (Evans et al., 2009). However, the general belief is that more natural environments, such as rural areas, provide a more suitable habitat for most species and thus for their conservation (Turner et al., 2004; Evans et al., 2009). Indeed, human settlements in rural and urban areas differ in many structural and biotic components and even in human attitudes concerning wildlife (Lepczyk et al., 2004). In urban landscapes, the presence of wildlife is limited by the availability of habitats, human disturbance, collisions with vehicles and behavioral shyness (Ditchkoff et al., 2006).
Previous studies on insects have demonstrated that urban habitats may not be as restrictive as expected (Owen \& Owen, 1975; Zapparoli, 1997). In addition, it has been observed that species richness and abundance can greatly vary within each city, indicating that different levels of urbanization have distinct effects on the local insect fauna (Owen \& Owen, 1975; Frankie \& Koehler, 1978; Zapparoli, 1997; McIntyre, 2000; McIntyre et al., 2001).

Information about the responses of wasps to urbanization is important for a number of reasons. Many wasp species, especially the eusocial ones, are key predators ecosystems (LaSalle \& Gauld, 1993). Wasps are sensitive to variations in abiotic conditions (e.g. temperature, luminosity and moisture), which may be related to changes in the urbanization level (Morgan \& Jeanne, 1992). In addition, wasps are frequently found in urban environments, efficiently occupying different microhabitats (Saure, 1996; Raw, 1998). 
In the south of the Iberian Peninsula, Polistes species are widespread both in natural landscapes and in anthropogenic habitats, where the presence of the wasps usually alarm people living near the nests. Numerous media campaigns have increased interest in this issue and have heightened the concerns of city inhabitants. This fear, which is not always fully justified, causes that people massively inform municipal services about practically all of the observed colonies of wasps. Despite their ecological importance and their potential as indicators of environmental conditions (Brown, 1991), few authors have analyzed the effects of urbanization on wasp assemblages in the Iberian Peninsula. In 1985 a study was conducted to analyze the influence of urban conditions on wasps and bees in the city of Salamanca (Gayubo \& Torres, 1990).These authors found that urbanization do not affect the populations of Polistes dominula (Christ, 1791) and Polistes gallicus (L., 1767). In addition Casamitjana (1989) studied some aspects related with the nesting of a small semiurban population of $P$. dominula located inside a brick-structure in an open space in the city of Barcelona. In Europe, the most complete study about nesting habits of $P$. dominula in urban areas was the conducted by Höcherl and Tautz (2015) in Würzburg (Germany). These authors concluded that $P$. dominula wasps are very flexible in their nesting behavior and that nesting itself is strongly linked to temperature conditions. Outside its natural range only Downing (2012) provides information about nest parameters of $P$. dominula, concluding that this species uses a wide range of nesting spots, some of which provided little shelter for the nest and were not locations that either of the native species would be found using.

The objective of this work was to verify the occurrence of Polistes species and the substrates used for nesting in urban areas in south-western Iberian Peninsula. We also took into account the height at which the nest was located and its orientation in relation to the north (azimuth).

\section{Materials and Methods}

From March to August of 2018, Polistes nests were surveyed in three small towns in the Llanos de Olivenza region (SW Spain): Olivenza (OL; 12,008 inhabitants; urban area: $1,358,300 \mathrm{~m}^{2} ; 38^{\circ} 41^{\prime} 8.03^{\prime \prime} \mathrm{N}, 7^{\circ} 6^{\prime} 3.24^{\prime \prime} \mathrm{W}$; alt., 265 $\mathrm{m}$ a.s.1.), San Francisco (SF; 466 inhabitants; urban area: $112,300 \mathrm{~m}^{2}$; 38 $44^{\prime} 47.37^{\prime \prime} \mathrm{N}, 7^{\circ} 6^{\prime} 18.81^{\prime \prime} \mathrm{W} ; 264 \mathrm{~m}$ a.s.l.) and San Benito (SB, 575 inhabitants; urban area: 166,200 $\mathrm{m}^{2}$; 38 $37^{\prime} 55.99^{\prime \prime} \mathrm{N}, 7^{\circ} 9^{\prime} 28.67^{\prime \prime} \mathrm{W} ; 223 \mathrm{~m}$ a.s.l.). In the Llanos de Olivenza region the climate is typically ContinentalMediterranean with relatively cold wet winters and dry hot summers (mean temperature: $16.3{ }^{\circ} \mathrm{C}$, rainfall: $432 \mathrm{~mm} \mathrm{yr}^{-1}$ ). Its flat to gently undulating landscape is dominated by a mosaic of dry winter cereal crops, olive groves, and vineyards.

Nest abundance was estimated along line transects of $100 \mathrm{~m}$ in each town. For each nest the species and the status: active, abandoned or old was recorded. We consider a nest as active when we detect the presence of wasps on the nest. In this case, the number of foundresses was recorded after detection of the respective nest and verified during the following weeks, until the first workers emerged. Abandoned nests have the same structure and color as an occupied nest, they are usually gray-white nests with well-defined and undamaged edges. Abandoned nests were visited for three consecutive days at different times to verify the absence of wasps. Old nests are nests from previous years, they are generally darker in color than occupied nests, and their edges are irregular and their structure is damaged. In many occasions they appear broken or partially sagged. Binoculars were used to observe and identify the species on high nests. Active nests were left in place after species identification was noted for each nest. For species identification keys Schmid-Egger et al. (2017) were used. Collected nests and wasps were deposited as voucher specimens in the Zoology Department insect collection (University of Extremadura, Badajoz, Spain).

The next features were estimated for each nest: height (using a laser distance meter), orientation (using a digital compass), and substrate (clay roof tile, CRT; corrugated asbestos, CA; direct on wall, DW; metal tubes, MT; noncylindrical metallic structures, NCM; plant material, PM; others, OT). Localization, height and orientation were estimated just above the nest, and in the case of the height from the soil to the nest.

Differences in height of the nests between species were tested with the Mann-Whitney U test. The preferences between substrates were tested by $\chi^{2}$ tests. We used Program ORIANA (Kovach, 2011) to calculate circular statistics for nest orientation: mean angle and circular standard deviation (c.s.d). Rayleigh's test of uniformity was used to test mean exposures for nonrandom orientations (Batschelet, 1981). Concentration ( $r$ ) or length of the mean vector was calculated by circular methods, ranges from 0 to 1 and is affected by variation in circular data, sample size, and grouping. Values of $r$ near 1 indicate data points closely concentrated near the mean angle or, in our case, nest-sites with a preferred directional orientation. Differences in mean direction between years were analyzed using the parametric Watson-Williams F-test in the cases where the assumptions underlying this test were fulfilled (Batschelet, 1981).

\section{Results}

A total of 744 wasp nests were found in the surveys, of which 583 were not active and 161 were active. Of the active nests 106 were occupied by $P$. dominula and 55 by $P$. gallicus (Table 1). The nests of $P$. dominula were significantly more abundant in Olivenza $\left(\chi^{2}=13.16, \mathrm{p}<0.001\right)$ and San Benito $\left(\chi^{2}=17.00, \mathrm{p}<0.001\right)$, while the nests of $P$. gallicus were more abundant in San Francisco, but the differences were not significant $\left(\chi^{2}=0.51, \mathrm{p}=0.5102\right)$. Overall, nests of $P$. dominula were significantly more abundant than nests of $P$. gallicus $\left(\chi^{2}=16.5, \mathrm{p}<0.001\right)$. In the case of $P$. dominula the number of foundresses per nest ranged between one and 
four $(1.9230 \pm 0.7344)$, whereas in the case of $P$. gallicus the number of foundresses per nest ranged between one and tree $(1.1750 \pm 04464)$. Thus, we determined a ratio of $29.79 \%$ single-versus $70.51 \%$ multiple- foundress colonies for $P$. dominula, and a ratio of $84.62 \%$ single-versus $15.38 \%$ multiple- foundress colonies for P. gallicus. The multiple foundation was significantly higher in $P$. dominula than in $P$. gallicus $\left(\chi^{2}=39.36, \mathrm{p}<0.001\right)$.

The mean number of active nests per transect was higher in San Francisco than in San Benito and Olivenza (Table 2). The same occurred with the mean number of nonactive nests and the mean number of total nests. Similarly, the number of active nests per $100 \mathrm{~m}$ was greater in San Francisco (4.60) than in San Benito (3.48) and Olivenza (1.68, Table 2).

Among the 753 colonies registered, the most used nesting substrate was clay roof tile in $60.02 \%\left(\chi^{2}=30.28\right.$,
Table 1. Number of nests in each of the sampled localities.

\begin{tabular}{lcccc}
\hline Town & \multicolumn{2}{c}{ Active nests } & $\begin{array}{c}\text { Non active } \\
\text { nests }\end{array}$ & Total \\
\hline & P. dominula & P. gallicus & & \\
Olivenza & 52 & 21 & 382 & 455 \\
San Benito & 32 & 7 & 95 & 134 \\
San Francisco & 22 & 27 & 106 & 155 \\
\hline
\end{tabular}

$\mathrm{p}<0.0001$ ) of the records (Fig 1 ). Secondly, nets build directly on walls represented with $10.09 \%$, followed by metals with $9.63 \%$ of nest found; the fourth position was occupied by plant material with $6.64 \%$, followed by glass corrugated asbestos with $4.78 \%$. The others categories include nests found on glass, plastic, and wood (in door, windows). In the case of the species, both $P$. dominula and $P$. gallicus preferred the clay roof tile as a material to build their nests.

Table 2. Average abundance of active and non-active nests in the localities studied and relative abundance of nests with respect to the urban area and the number of inhabitants.

\begin{tabular}{lcccccrr}
\hline Town & Active nests & $\begin{array}{c}\text { Non active } \\
\text { nests }\end{array}$ & Total & $\begin{array}{c}\text { Active } \\
\text { nest/100 m }\end{array}$ & $\begin{array}{c}\text { Non active } \\
\text { nest/100 m }\end{array}$ & $\begin{array}{c}\text { An active nest } \\
\text { for each... }\end{array}$ & \multicolumn{1}{c}{ An active nest by } \\
\hline Olivenza & $0.55 \pm 0.94$ & $2.80 \pm 3.28$ & $3.40 \pm 3.81$ & 1.68 & 0.29 & $15344 \mathrm{~m}^{2}$ & 148 inhabitants \\
San Benito & $2.38 \pm 1.53$ & $5.04 \pm 2.29$ & $7.42 \pm 2.83$ & 3.48 & 1.10 & $2825 \mathrm{~m}^{2}$ & 15 inhabitants \\
San Francisco & $2.60 \pm 2.06$ & $6.33 \pm 3.64$ & $8.93 \pm 3.91$ & 4.60 & 1.48 & $1986 \mathrm{~m}^{2}$ & 9 inhabitants \\
\hline
\end{tabular}

The height of nests was $4.88 \pm 1.59 \mathrm{~m}$ (range: 0.15 $14 \mathrm{~m}$ ) in Olivenza, $3.28 \pm 1.14 \mathrm{~m}$ (range: $1.3-7.0 \mathrm{~m}$ ) in San Benito, and 3.35 $\pm 1.04 \mathrm{~m}$ (range: 1.6-7.0 m) in San Francisco. Mean overall height of nests was $4.23 \pm 1.57 \mathrm{~m}$ (range: 0.15 $14 \mathrm{~m})$. The height of the nests did differed between the three tows (Kruskal-Wallis test, $\mathrm{H}=164.54, \mathrm{p}<0.001$ ).
In all the tree towns nests exposure were oriented to the southeast (SE) with mean angle values oscillating between $127.42^{\circ}$ and $140.68^{\circ}$ (Table 3 ). The length of the mean vector oscillated between 0.477 and 0.748 . In all cases nests were significantly oriented on SE direction (Raleigh's Z test). Differences in nest orientations were only significantly

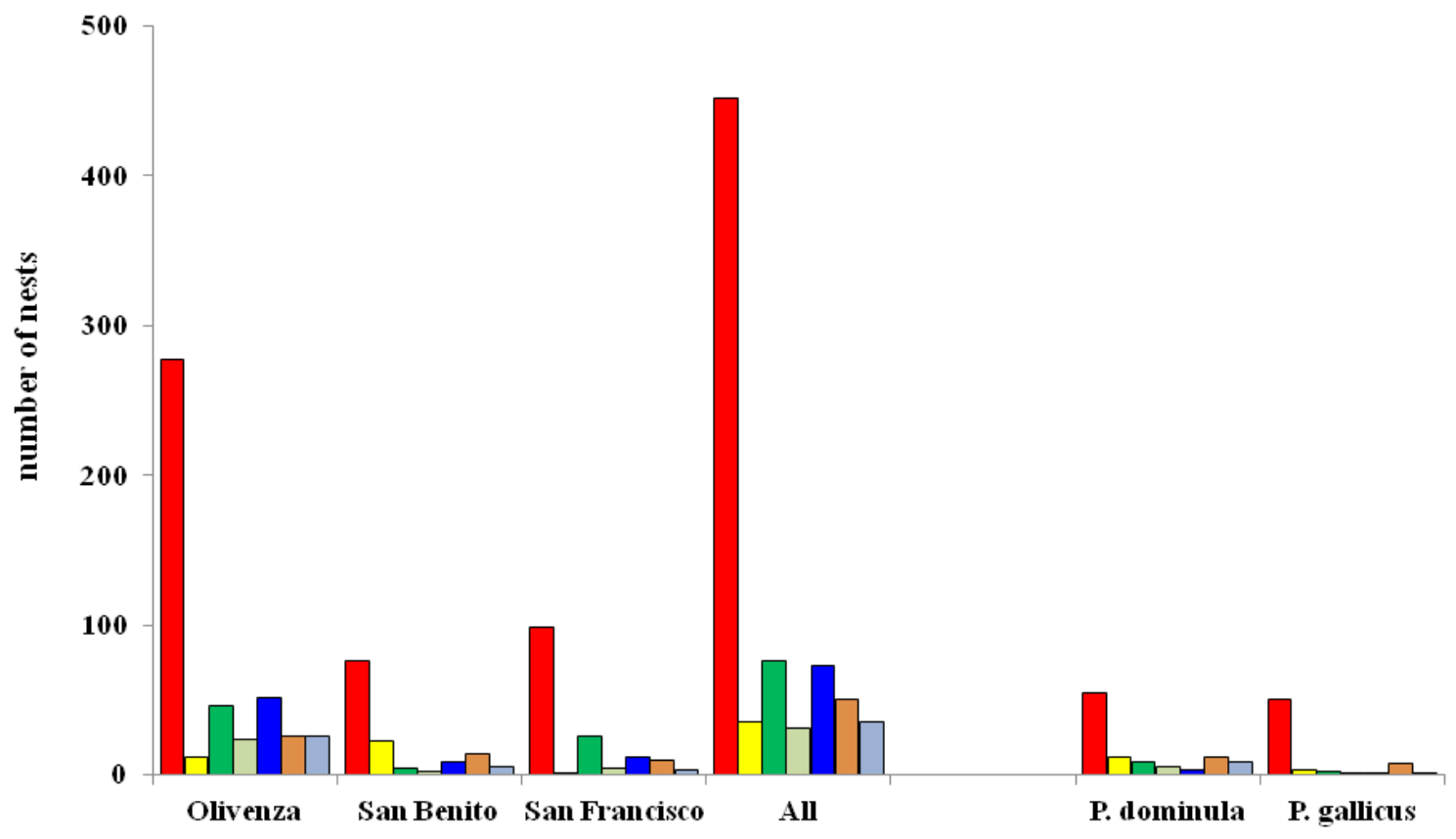

Fig 1. Type of substrate selected by wasps in each city and by species (clay roof tile, CRT; corrugated asbestos, CA; direct on wall, DW; metal tubes, MT; non-cylindrical metallic structures, NCM; plant material, PM; others, OT). 
between San Francisco and San Benito (Watson-Williams F-test, $F=4.3946, p=0.036)$. Overall, nests were oriented to the SE with a mean vector of $131.94^{\circ}$ and a length of mean vector of 0.474 (Table 3 ). Nests were significantly oriented to the SE (Raleigh's $Z=163.746, \mathrm{p}<0.0001$ ). The analysis by species showed that nests of $P$. dominula and $P$. gallicus were significantly oriented to the SE (Table 3) and their orientations did not differed (Watson-Williams F-test, $F=0.8199, \mathrm{p}=0.368$ ).

Table 3. Nest orientations in the three sampled localities and by species.

\begin{tabular}{lcccc}
\hline Town & Mean angle \pm c.s.d & $\begin{array}{c}\text { Length of the } \\
\text { mean vector (r) }\end{array}$ & Raleigh's Z & p value \\
\hline Town & & & & \\
$\quad$ Olivenza & $128.55^{\circ} \pm 69.76^{\circ}$ & 0.477 & 109.903 & $<0.0001$ \\
San Benito & $140.68^{\circ} \pm 62.14^{\circ}$ & 0.555 & 41.326 & $<0.0001$ \\
San Francisco & $127.42^{\circ} \pm 43.62^{\circ}$ & 0.748 & 91.847 & $<0.0001$ \\
All towns & $131.94^{\circ} \pm 70.01^{\circ}$ & 0.474 & 163.746 & $<0.0001$ \\
Species & & & & \\
P. dominula & $142.79^{\circ} \pm 36.99^{\circ}$ & 0.812 & 35.593 & $<0.0001$ \\
$P$. gallicus & $149.76^{\circ} \pm 51.61^{\circ}$ & 0.667 & 47.089 & $<0.0001$ \\
\hline
\end{tabular}

\section{Discussion}

It is generally assumed that urbanization reduces habitat complexity, mostly by reducing natural vegetation cover. Consequently, it may be predicted that less urbanized areas are structurally more complex. For these reasons, it can also be predicted that less urbanized areas support a greater abundance and species richness of wasps and bees (Zanette et al., 2005). Previous works (Torres \& Gayubo, 1989; Zanette et al., 2005) have demonstrated that wasps were more abundant in the less or non-urbanized areas of cities. Our results seem to confirm these predictions, as we have shown that in both species the number of nests decreases with increasing levels of urbanization (square meters built, number of inhabitants). According to Zanette et al. (2005) the reduction in prey availability caused by the loss of vegetation may be one of the factors responsible for these results. In addition, the increase of pavements and buildings coupled with the reduction of vegetation cover increases the exposure of wasp colonies to possible predators and particularly to humans, which are the major cause of colony mortality in urban environments (Fowler, 1983).

One of the advantages of built nests in urban environments is the reduction of the competence for nesting sites (da Silva et al., 2019). P. dominula and P. gallicus are the only synanthropic wasps species in the Iberian Peninsula (Gayubo \& Torres, 1990) and the observed differences in nest abundance between these species in this study may be related with their biological traits. As a primitively eusocial wasp, the cooperation of queens in nest building and brood care of Polistes species is common (Reeve, 1991). We detected maximal four foundresses (in P. dominula) per nest during the study period. This number of foundresses is in contrast with observations made in other studies. For instance, Zanette and Field (2009) recorded nest buildings of $P$. dominula wasps by 1-10 foundresses in southern Spain. The colonies of $P$. gallicus are founded by a single foundress in open locations
(Cervo \& Turillazzi, 1985). In our study it became apparent that $P$. gallicus preferred single over multiple foundation of colonies contrary to $P$. dominula. For this species Turillazzi et al. (1982) determined a ratio of $36 \%$ single-versus $64 \%$ multiple- foundress colonies and Zanette and Field (2011) described a ratio of $7 \%$ single versus $93 \%$ multiple-founded nests. However, in Germany (Höcherl \& Tautz, 2015) the hibernating queens of $P$. dominula neither preferred multiple nor single founding ( $46 \%$ and $54 \%$, respectively). One of the advantages of multiple founding is that the survival of nests increases in relation to single founding. Another benefit of multiple-foundress nests is an increased productivity as measured by the number of cells per nest (Queller et al., 2000; Tibbetts \& Reeve, 2003). In addition, we have observed at our three study sites that $P$. dominula hibernating foundress emerges before and produces its first workers earlier than $P$. gallicus. According to Gamboa et al. (2002) early worker production enhances productivity.

Polistes dominula may have other advantages over $P$. gallicus in addition to those we have considered. For example, $P$. dominula is less demanding than $P$. gallicus in relation to the selection of the nesting sites. Downing (2012) demonstrated in the United States (where $P$. dominula is an invasive species), that $P$. dominula used a wide range of nesting spots, some of which provided little shelter for the nest and were not locations that either of the native species would be found using. In this way, Gamboa et al. (2002) suggested that nesting sites may be a limiting resource, and its use of a wider diversity of nesting locations may provide some competitive advantages.

The nesting sites chosen by wasps are strongly influenced by predation and the weather (Jeanne, 1970). Nesting on manmade substrates, in addition to natural ones, may be a useful strategy for wasp populations since their colonies may have higher developmental success as these locations may allow them to avoid their natural predators and take shelter from harsh weather conditions (Alvarenga et al., 2010). Polistes 
species may build their nest in man-made structures, such as eaves (Cervo \& Turillazzi 1985) or attics (Rusina et al., 2007), where metal, concrete, ceramic, stone, plastic, porcelain, asbestos, synthetic materials, and wood are highlighted as the substrates chosen by wasps in urban areas (Lima et al., 2000; Detoni et al., 2018). The apparent preference of the wasp for nesting under clay roof tiles (or Arabian tile) might be related to the greater offer of this substrate in comparison to the others. Probably in the Iberian Peninsula the tile is the material most used to cover the houses, especially in small towns and cities where buildings do not predominate. Tiles are made of clay, are curved and protrude about $10-20 \mathrm{~cm}$. With a thickness of $10-15 \mathrm{~mm}$ they provide excellent protection against cold and rain. The second category most used by wasps was metal tubes. Some authors (Lola et al., 2013; Virgínio et al., 2016) have suggested that this preference was probably related with a phenomenon known as "heat islands"; the accumulated heat over the metallic superficies provides suitable conditions for the colonies to develop. We cannot rule out this fact, but in the south of the Iberian Peninsula very high temperatures are recorded in July and August, which can cause the death of the colony. In fact, most of the nests built on metallic tubes were located during the warmest months. According with da Silva et al. (2019) the results might have been affected by each nesting substrate type availability rate in the area rather than preference.

In this study nest height above ground $(0.15-12 \mathrm{~m})$ is greater than the reported for European species of Polistes in natural habitats (15-25 cm, Kozyra et al., 2016; 4-60 cm, Cervo \& Turillazzi, 1985). This is no surprise, as wasps take advantage of the height of human structures to build their nests. In a similar study conducted in Brazil (Virgílio et al., 2016) nest were located at 2-4 $\mathrm{m}$ above ground. We are agreeing with Kozyra et al. (2016) that nest height plays an important role in protecting the nest from predators. In this way we suppose, as occurs in birds (Mainwaring et al., 2014), that wasps vary the height at which they build their nests in response to predators, as they build their nests higher from the ground in response to mammalian and ant predators and lower in response to avian predators.

In many social insects, such as ants and termites, the geographic orientation of nests is not accidental and is of great significance for their thermoregulation (Jones \& Oldroyd, 2006). Nest orientation often influences the amount of solar radiation absorbed by a nest and the time of day that the highest radiation is received. Many species orientate their nests so that it is warmed by solar radiation in the cool of the morning (Jones \& Oldroyd, 2006). The orientation of nets of Polistes in our study $\left(131.94^{\circ}\right)$ is very similar to those reported for $P$. nimpha in Poland $\left(110^{\circ}\right.$, Kozyra et al., 2016), and in Italy $\left(162^{\circ}\right.$, Cervo \& Turillazzi, 1985) and agree with orientations reports by Yamane (1996) for P. snelli and $P$. biglumis (southern and southeastern slopes). Although the above examples are for non-urban populations, the trend appears to be the same. In tropical areas the situation seems to be quite different, as occurs in Brazil for example with other vespids. In the State of Minas Gerais most colonies of Mischocyttarus cassununga (Vespidae, Mischocyttarini) were north-oriented, between northwest and northeast, $271^{\circ}$ to $90^{\circ}$ (de Castro et al., 2014). In the Lower Amazon, colonies of $M$. drewseni were mainly oriented to the west (Jeanne, 1972). In the State São Paulo nests of M. cerberus styx were oriented to the east (Giannotti, 1999), and in the State of Mato Grosso do Sul Montagna et al. (2010) did not find a preference for a particular nest orientation in Mischocyttarus consimilli. However, for P. canadiensis Virgílio et al. (2016) have pointed out that most of nests were oriented to the East. These results confirm that at least in temperate areas nest orientation is not accidental.

According to Sumner et al. (2018) scientists may provide robust evidence on the ecological and economic value of wasps to convince the public to view these insects favourably. An overall increase of scientific understanding could, in turn, help to improve the public's perception of wasps. If this were achieved, we expect that the public would be more accommodating of wasps and more inclined to tolerate wasp nests in their local environment, rather than have them removed. Increased tolerance will benefit the conservation of these important insects even in urban environments.

\section{Acknowledgements}

We sincerely thank people for Olivenza, San Francisco de Olivenza and San Benito de la Contienda for help and collaboration during the realization of this study. CMR was supported by a Departmental collaboration grant Ministry of Education, Spanish Government.

\section{References}

Alvarenga, R.B., Castro, M.M., Santos-Prezoto, H.H. \& Prezoto, F. (2010). Nesting of social wasps (Hymenoptera, Vespidae) in urban gardens in Southeastern Brazil. Sociobiology, 55: 445-452.

Batschelet, E. (1981). Circular statistics in Biology. New York: Academic Press, 371 p.

Brown, K. (1991). Conservation of Neotropical environments: insects as indicators. In N.M. Collins \& J.A. Thomas (Eds.). The conservation of insects and their habitats (pp. 349-404). London: Academic Press.

Casamitjana, J. (1989). Aspectes ecoetólogics de les vespes del gènere Polistes de Catalunya (i): estudi de la nidificació d'una població semiurbana de Polistes dominulus Christ, 1791 (Hymenoptera: Vespidae). Sessions Entomológicas ICHNSCL, VI: 87-96.

Cervo, R. \& Turillazzi, S. (1985). Associative foundation and nesting sites in Polistes nimpha. Naturwissenschaften, 72: 4849. doi: 10.1007/BF00405334 
Da Silva, R.C., Prato, A.S. \& Nascimento, F.S. (2019). Occurrence and nesting behavior of social wasps in an anthropized environment. Sociobiology, 66: 381-388. doi: 10.13102/sociobiology.v66i2.4303

De Castro, M.M., Guimarães de Alvear, D.L., de Souza, A.R. \& Prezoto, F. (2014). Nesting substrata, colony success and productivity of the wasp Mischocyttarus cassununga. Revista Brasileira de Entomologia, 52: 168-172.

Detoni, M.F.D.F.S., Barbosa, B.C., Maciel, T.T., dos Santos, S.J.L. \& Prezoto, F. (2018). Long-and short-term changes in social wasp community structure in an urban area. Sociobiology, 65: 305-311. doi: 10.13102/sociobiology. v65i2.2597.

Ditchkoff, S.S., Saalfeld, S.T. \& Gibson, C.J. (2006). Animal behavior in urban ecosystems: modifications due to humaninduced stress. Urban Ecosystems, 9: 5-12. doi: 10.1007/s11 252-006-3262-3

Downing, H. (2012). Nest parameters of Polistes and Mischocyttarus species (Hymenoptera: Vespidae) before and after detection of the invasive wasp, Polistes dominula in Western South Dakota and Wyoming. Journal of the Kansas Entomological Society, 85: 23-31.

Evans, K.L., Newson, S.E. \& Gaston, K.J. (2009). Habitat influences on urban avian assemblages. Ibis, 151: 19-39.

Fowler, H.G. (1983). Human effects on nest survivorship of urban synanthropic wasps. Urban Ecology, 7: 137-143. doi: 10.1016/0304-4009(83)90032-3

Frankie, G.W. \& Koehler, L.E. (1978). Ecology of insects in urban environments. Annual Reviews in Entomology, 23: 367-387.

Gamboa, G.J., Greig, E.I. \& Thom, M.C. (2002). The comparative biology of two sympatric paper wasps, the native Polistes fuscatus and the invasive Polistes dominulus (Hymenoptera,Vespidae). Insectes Sociaux, 49: 45-49. doi: 10.1007/s00040-002-8278-y

Gayubo, S.F. \& Torres, F. (1990). Efecto de la presión urbana sobre abejas y avispas (Hymenoptera, Aculeata) en Salamanca. III: Eumenidae y Vespidae. Studia Oecologica, 7: 101-115.

Giannotti, E. (1999). Arquitetura de ninhos de Mischocyttarus cerberus styx Richards, 1940 (Hymenoptera, Vespidae). Revista Brasileira de Zoociências, 1: 7-18.

Grimm, N.B., Faeth, S.H., Golubiewski, N.E., Redman, C.L., Wu, J., Bai, X. \& Briggs J.M. (2008). Global change and the ecology of cities. Science, 319: 756-760. doi: 10.1126/ science. 1150195

Höcherl, N. \& Tautz, J. (2015). Nesting behavior of the paper wasp Polistes dominula in Central Europe-a flexible system for expanding into new areas. Ecosphere, 6(12): 262. doi: 10.1890/ES15-00254.1

Jeanne, R.L. (1970). Chemical defense of broad by a social wasp. Science, 168: 1465-1466.
Jeanne, R.L. (1972). Social biology of the Neotropical wasp Mischocyttarus drewseni. Bulletin of the Museum of Comparative Zoology, 144: 63-150.

Jones, J.J. \& Oldroyd, B.P. (2006). Nest thermoregulation in social insects. Advances in Insect Physiology, 33: 153-191. doi: 10.1016/S0065-2806(06)33003-2

Kovach, W.L. (2011). Oriana. Circular Statistics for Windows, ver. 4. Kovach Computing Services. Pentraeth.

Kozyra, K.B., Baraniak, E. \& Kasprowicz, M. (2016). Nesting ecology of Polistes nimpha (Hymenoptera, Vespidae): a preliminary study in western Poland. Journal of Hymenopteran Research, 51: 187-201. doi: 10.3897/jhr.51.7508

LaSalle, J. \& Gauld, I.D. (1993). Hymenoptera: their diversity, and their impact on the diversity of other organisms. In J. LaSalle \& I.D. Gauld, (Eds.), Hymenoptera and biodiversity (pp. 1-26). Oxon: CAB International.

Lepczyk, C.A., Mertig, A.G. \& Liu, J. (2004). Assessing landowner activities related to birds across rural-to-urban landscapes. Environmental Management, 33: 110-125. doi: 10.1007/s00267-003-0036-z

Lima, M.A.P., Lima, J.R. \& Prezoto, F. (2000). Levantamento dos gêneros, flutuação das colônias e hábitos de nidificação de vespas sociais (Hymenoptera, Vespidae) no Campus da UFJF, Juiz de Fora, MG. Revista Brasileira de Zoociências, 2: 69-80.

Lola, A.C., Uchoa, P.W., Júnior, J.A.S., Cunha, A.C. \& Feitosa, J.R.P. (2013). Variações termo-higrométricas e influências de processo de expansão urbana em cidade equatorial de médio porte. Brazilian Geographical Journal: Geosciences and Humanities Research Medium, 4: 615-632.

Mainwaring, M.C., Hartley, I.R., Lambrechts, M.M. \& Deeming Ch. (2014). The design and function of birds' nests. Ecology and Evolution, 20: 3909-3928. doi: 10.1002/ ece3.1054

McIntyre, N.E. (2000). Ecology of urban arthropods: a review and a call to action. Annals of the Entomological Society of America, 93: 826-835.

McIntyre, N.E., Rango, J., Fagan, W.F. \& Faeth, S.H. (2001). Ground arthropod community structure in a heterogeneous urban environment. Landscape Urban Planning, 52: 257-274. doi: 10.1016/S0169-2046(00)00122-5

Montagna, T.S., Torres, V.O., Fernandes, W.D. \& AntonialliJunior, W.F. (2010). Nest architecture, colony productivity, and duration of immature stages in a social wasp, Mischocyttarus consimilis. Journal of Insect Sciences, 10 (191): 1-12. doi: 10.1673/031.010.19101

Morgan, R. \& Jeanne, R. (1992). The influence of temperature on nest site choice and reproductive strategy in a temperate zone Polistes wasp. Ecological Entomology, 17: 135-141. 
doi: 10.1111/j.1365-2311.1992.tb01170.x

Owen, J. \& Owen, D.F. (1975). Suburban gardens: England's most important reserve? Environmental Conservation, 2: 5359. doi: $10.1017 / \mathrm{S} 0376892900000692$

Queller, D.C., Zacchi, F., Cervo, R., Turillazzi, S., Henshaw, M.T., Santorelli, L.A. \& Strassmann, J.E. (2000). Unrelated helpers in a social insect. Nature, 405: 784-787. doi: 10.10 $38 / 35015552$

Raw, A. (1998). Population densities and biomass of neotropical social wasps (Hymenoptera, Vespidae) related to colony size, hunting range and wasp size. Revista Brasileira de Zoologia, 15: 815-822.

Reeve, H.K. (1991). Polistes. In K.G. Ross \& R.W. Matthews (Eds.), The social biology of wasps (p. 99-148). New York: Cornell University Press.

Rusina, L.Yu., Rusin, I.Yu., Starr, C.K., Fateryga, A.B. \& Firman, L.A. (2007). Modes of colony foundation by females of different morphotypes in the paper wasps (Hymenoptera, Vespidae, Polistes Latr.). Entomological Reviews, 87: 11551173. doi: $10.1134 / \mathrm{S} 0013873807090060$

Saure, C. (1996). Urban habitats for bees: the example of the city of Berlin. In A. Matheson, S.L. Buchmann, C. O’Toole, P. Westrich \& I.H. Williams (Eds.), The conservation of bees (pp. 47-53). San Diego: Academic Press.

Schmid-Egger, C., Van Achterberg, K., Neumeyer, R., Morinière, J. \& S. Schmidt (2017). Revision of the West Palaearctic Polistes Latreille, with the descriptions of two species - an integrative approach using morphology and DNA barcodes (Hymenoptera, Vespidae). ZooKeys, 713: 53-112. doi: 10.38 97/zookeys.713.11335

Sumner, S., Law, G. \& Cini, A. (2018). Why we love bees and hate wasps. Ecological Entomology, 43: 836-845. doi: 10.1111/een.12676.

Tibbetts, E.A. \& Reeve, H.K. (2003). Benefits of foundress associations in the paper wasp Polistes dominulus: increased productivity and survival, but no assurance of fitness returns.
Behavioral Ecology, 14: 510-514. doi: 10.1093/beheco/arg037

Torres, F. \& Gayubo, S.F. (1989). Efecto de la presión urbana sobre abejas y avispas (Hymenoptera, Aculeata) en Salamanca. V: Superfamilia Apoidea. Comunicaciones I. N. I. A. (serie recursos naturales), vol. 54, 49 pp.

Turillazzi, S., Marino-Piccioli, M.T., Hervatin, L. \& Pardi, L. (1982). Reproductive capacity of single foundress and associated foundress females of Polistes gallicus (L.) (Hymenoptera, Vespidae). Monitore Zoologico Italiano, 16: 75-88.

Turner, W.R., Nakamura, T. \& Dinetti, M. (2004). Global urbanization and the separation of humans from nature. Bioscience, 54: 585-590. doi: 10.1641/0006-3568(2004)054\% 5B0585:GUATSO\%5D2.0.CO;2

Virgínio, F., Maciel, T.T. \& Barbosa, B.C. (2016). Hábitos de nidificação de Polistes canadensis (Linnaeus) (Hymenoptera: Vespidae) em área urbana. EntomoBrasilis, 9: 81-83. doi: 10.12741/ebrasilis.v9i2.586.

Yamane, S. (1996). Ecological factors influencing the colony cycle of Polistes wasps. In Turillazzi, S. \& West-Eberhard M.J. (Eds.), The Natural History and Evolution of Paper Wasps (p. 75-97). London: Oxford University Press

Zanette, L.R.S. \& Field, J. (2009). Cues, concessions, and inheritance: dominance hierarchies in the paper wasp Polistes dominulus. Behavioral Ecology, 20: 773-780. doi: 10.1093/ beheco/arp060

Zanette, L.R.S. \& Field, J. (2011). Founders versus joiners: group formation in the paper wasp Polistes dominulus. Animal Behaviour, 82: 699-705. doi: 10.1016/j.anbehav.2011.06.025

Zanette, L.R.S., Martins, R.P. \& Ribeiro, S.P. (2005). Effects of urbanization on Neotropical wasp and bee assemblages in a Brazilian metropolis. Landscape and Urban Planning, 71: 105-121. doi: 10.1016/j.landurbplan.2004.02.003

Zapparoli, M. (1997). Urban development and insect biodiversity of the Rome area, Italy. Landscape and Urban Planning, 38: 77-86. doi: 10.1016/S0169-2046(97)00020-0 